\title{
Za lidskou důstojnost
}

\author{
Alexej Mikulášek (Nitra)
}

Monika Adamická: Slovenské židovstvo v tvorbe Antona Baláža. Nitra: FSŠ UKF v Nitre, 2019. 116 s. ISBN 978-80-558-1427-8.

$\mathrm{V}$ rámci řešení vědecko-výzkumného projektu (UGA X/1/2019) nazvaného Problematika povojnového židovstva v slovenskej literatúre s dôrazom na tvorbu Antona Baláža vyšla publikace mladé badatelky Moniky Adamické (doktorandky Ústavu středoevropských jazyků a kultur v Nitře), která svým významem překračuje hranice dílčí personální monografie a naznačuje další možnosti studia fenoménu židovské literatury a židovské identity ve středoevropském kulturním prostoru. Na úvod ještě připomeňme, že publikaci lektorovali Ján Gallik a Ivan Šuša a že ji autorka dedikovala „Antonovi Balážovi, ktorý mi venoval svoj čas, poskytol mi pomoc a cenné informácie pri pisani tejto publikácie“.

Monika Adamická vychází ze zjištění, že tematika „židovstva v slovenskej literatúre nie je novodobým fenoménom. S postavami Židov sa stretávame už v období klasicizmu v 19. storoči. Druhá svetová vojna zásadným spôsobom meni pohlad na slovenské židovstvo. Postavy Židov, vykreslených v negatívnom zmysle, ako bolo zuykom v obdobi pred druhou svetovou vojnou, sa menia na postavy, ktorých životy boli poznačené hrôzami rasového prenasledovania a genocídy páchanej na židouskom národe. Vyobrazenie Židov ako lakomcov, úžernikov, profitujúcich na zbedačenom slovenskom národe, sa stáva prekonaným" (s. 7). A právě na podoby onoho „poválečného překonávání" se autorka soustředí, jakkoliv hlavní pozornost přirozeně věnuje tvorbě Antona Baláže.

Pokud ponecháme stranou kapitolu úvodní a závěrečnou (stejně jako bibliografii a jmenný rejstř́ík), je kniha roztř́íděna do šesti základních kapitol, vnitřně dále členěných, nazvaných $A n$ ton Baláž, Antisemitizmus počas vojny a po vojne, Židia v slovenskej literatúre, Transporty nádeje, Ofélia nie je mŕtva, a Poviedky a novela so židovskou te- matikou (pojednávající o prózách nazvaných Krajina zabudnutia, Trhlina a Šimon Pútnik). Za nejcennější pokládám už kapitolu nazvanou Židia $v$ slovenskej literatúre (s. 25-44). Podle autorky jsou při zobrazování židovské problematiky v literatuře před druhou světovou válkou patrné dvě tendence (či „dva hlavné motívy“, s. 26), a to jednak „vykreslenie Žida, ktorý žije na úkor zbedačeného, alkoholom skazeného slovenského l'udu“, což je způsobeno tím, že slovenský lid žije v bídě, „ktorá je aj pričinou, prečo sa utieka $k$ alkoholizmu, prečo je nútený si požičiavat’ od Žida, krčmára a obchodnika, peniaze, a čo ho v konečnom dôsledku vedie do ešte vä̌řsej biedy“ (s. 26). Druhý motiv spatřuje ve snaze spisovatelů vysvětlit, proč „sa Žid správa týmto spôsobom, prečo sa venuje obchodu, krčme“; př́ičinou je dle nich skutečnost, že „Židia nežijú vo vlastnej krajine, nemajú svoj štát, svoju domovinu, na cudzom územi sa cítia ako v zajati" (tamtéž). Autorka připomíná díla Jozefa Ignáce Bajzy, Jonáše Záborského (o jeho Faustiádě soudí, že v ní nejde „len o výsmech židovstva, autor sa vysmieva všetkým, Nemcom i Slovákom, Židom rovnako ako antisemitom, ale aj iným náboženstvám a etnikám“, s. 28), Jozefa Gregora Tajovského, detailně se pak věnuje románu Gejzy Vámoše Odlomená haluz, v němž spisovatel vzdor „svojmu židovskému pôvodu sa [...] sarkasticky vyjadruje o Židoch, o ich spôsobe života a náboženskom fanatizme, o židouských náboženských rituáloch a praktikách, za čo ho židovská obec chcela vylúcit" (tamtéž, s. 29).

Obraz židů/Židů po druhé světové válce se proměňuje: „Aj v povojnovyých dielach sa sice môžeme stretnút's obrazom Žida ako lakomca, obchodnika, tieto motívy sa však stávajú druhoradými. Prvoradou sa stáva tragédia masového vyvraždovania Židov" (s. 33). Analytičtěji se M. Adamická věnuje románu Rudol- 
fa Jašíka Námestie svätej Alžbety (1958), novelám Františka Švantnera Sedliak (1965) a Leopolda Laholy (vl. jm. Leopold Arje Friedmann) Božia ulička (bratislavské Vydavatelství Spolku slovenských spisovatelov pod tímto titulem přineslo v roce 1998 antologii „slovenskej literatúry o holokauste“; editorem byl Milan Richter), románům Ladislava Mňačka Smrt’ sa volá Engelchen (1958, přičemž o postavě Marty Goldové oprávněně soudí, že „patrí k jedným z najtragickejšich postáv svetovej literatúry“; tamtéž, s. 39) a Kláry Jarunkové Čierny slnovrat (1979), próze Petra Karvaše Starý pán a osud a rovněž dramatu Antigona a tí druhí (1962). Z literatury s výraznou dokumentární funkcí pojednává především o dílech Jozefa Lánika (vl. jm. Alfréd Wetzler) Čo Dante nevidel (1965) a vzpomínkách Rudolfa Vrby (vl.jm. Valter Rosenberg) Utiekol som z Osvienčimu (2015), přičemž, jak je také známo, v obou případech jde o autory, „ktori na vlastnej koži prežili hrôzy koncentračného tábora v pol'skom Osvienčime. Obom sa však za spoluúčasti iných väzñov podarilo z tábora ujst', aby podali autentické správy slovenskej židovskej obci“ (tamtéž, s 42).

V literatuře po roce 1989 zaznamenává především „zvýšený záujem o vydávanie memoárovej literatúry o holokauste“, přičemž se někdy užívá pojem táborová či lágrová literatura. Osobitě se věnuje např. Milanu Richterovi (sbírce básní Vo mne zbúraný chrám, 2002), Vincentu Šikulovi (Erikine l'alie, 1996), Jánu Johanidesovi (Inzeráty pre večnost', 2002), Iboje Wandall-Holmové (Moruša, 1991), Juraji Špitzerovi (Nechcel som byt’ žid, 1994) a dalším, přičemž stranou neponechává ani zdařilou memoárovou knihu Denisy Fulmekové Konvália (s podtitulem Zakázaná láska Rudolfa Dilonga, 2016). Dodejme, že by si zasloužila i překlad do českého jazyka vzhledem $\mathrm{k}$ tomu, že čeští čtenáři přece jen preferují češtinu před, jakkoliv v zásadě plně srozumitelnou, literární slovenštinou.

Více než polovina monografie je přirozeně věnována právě tvorbě Antona Baláže s židovskou tematikou, a to v návaznosti na poetologické, genologické a jiné výzkumy Tibora Žilky. Týká se to především již připomínané Balážovy knihy Transporty nádeje (2010), inspirované dokumentem, který autor objevil v archivu v Novácích a pocházejícím z ledna roku 1950 (pro vystěhování do Izraele Židé museli úřadům dokazovat svůj původ pět let po skončení platnosti norimberských zákonů). Autorka poté pokračuje popisem a analýzou rozhlasové hry Ofélia nie je mŕtva z roku 2003, zvláště životních osudů Židovky Miriam, která po návratu domů zjištuje, že „okrem rodiny prišla aj o domov, rounako aj o priatelov" (tamtéž, s. 83); podle autorky v této tragické postavě Baláž zosobnil vše, s čím se židé/Židé po návratu z koncentračních táborů museli vyrovnávat. To platí i o ženských postavách prózy Krajina zabudnutia (2000), v níž „osobná skúsenost' z tábora smrti sa premietla aj do traumy z nahoty, do témy, ktorá sa stáva dôležitou súčastou deja novely“ (tamtéž, s. 87), nebo o povídkách Trhlina a Šimon Pútnik (2014). Škoda jen, že autorka nesrovnává tato díla s jinými artefakty, a to např. i české literatury, v portrétech židovských žen přeživších holocaust zvláště s postavami Arnošta Lustiga (Dita Saxová), Josefa Škvoreckého (Lví$\check{c}$ ) nebo s Helenou z filmu Milenci v roce jedna, snímku natočeného Jaroslavem Balíkem podle předlohy Jana Otčenáška (1973), pokud bychom měli zůstat - namátkově - jen u produkce české.

Za pozitivní rysy monografie pokládám mj. věcnost, stř́zlivost, srozumitelnost, snahu o přesnost formulací, jazykovou citlivost, zvláště pak detailní obeznámenost s dílem Antona Baláže. Fakt, že autorka mohla čerpat i z osobního archivu, resp. z korespondence a rozhovorů se spisovatelem, lze pokládat za pozitivní, nebot Baláž patří k autorům, kteří nepíší intuitivně, nepohrávají si se čtenářem, nechtějí vytvářet mytologický obraz sebe samého (ani svého díla), nevytvářejí obraz, v němž je vše relativní a jemuž „nelze věřit“. Je schopen reflexe svého slovesného díla, tedy i upozornit na ty vrstvy textu, jeho geneze a recepce, které by mohly zůstat čtenáři skryty. Výhodou monografie je skutečnost, že může sloužit jako studijní pomůcka, jako skriptum pro posluchače vysokých škol: místy máme dojem, že popisy a charakteristiky tematické stránky beletristických knih a vůbec tematické přehledy jsou tímto didaktickým záměrem motivovány.

Z monografie vyplývají minimálně dva podněty, které by snad bylo vhodné v dalším studiu 
na poli slovensko-židovském (a slovenskožidovském) rozvinout. První jen volně souvisí s recenzovanou publikací. Ačkoliv se výraz „antisemitizmus" v textu neobjevuje často, a je vždy prokazatelně doložený, pokládám za nutné diferencovat dva postoje: antisemitismus (antisemitikum) vystupuje jako výraz předsudečné neznalosti či nenávisti, jistě v různé intenzitě, ale vždy deformuje umění a estetiku v propagaci a agitaci, ve svého druhu instrument, nástroj, jednostranné médium primárně neliterárního záměru a smyslu (jakkoliv s jistou řemeslnou hodnotou, útočící na naše smysly a city). Naopak - kritický obraz postavy české, slovenské, polské, křestanské, muslimské stejně jako židovské ještě neznamená, že je tato postava portrétována jako „prototyp“ zla, jako předsudečný obraz, v němž např. židovská postava je negativní jen proto, že je židovská, že je reprezentantem „židovského zla“. Že to, co „dělá“ špatně, „dělá“ právě jako postava židovská, naopak to, co „dělá“ pozitivně, koná jako subjekt, jenž se s židovstvím rozešel.

Navíc je třeba zohledňovat interně literární, žánrová a jiná hlediska. Lze si snad vypomoci příkladem z literatury devatenáctého století. „Olejkár Hrabovec“ (z romantické historické novely J. M. Hurbana) je postava ambivalentní: je líčena s neskrývaně kritickou tendencí a vyhraněně konfrontačně (polaritně: zločinec Olejkár versus ušlechtilý Matúš Trenčiansky) a představuje známý fiktivní portrét, ovšem s rysy blízkými antisemitské ikonografii 19. a první poloviny 20. století (odpudivá fyziognomie, až d’ábelské charakterové rysy, zavrženíhodná mo- tivace jednání, oddělené místo jeho života etc.). Plní však funkce vlastní romantické historické pověsti s pohádkovými a barvitě dobrodružnými prvky, jakési romantické populární literatury. Postrádá židovskou identitu; snad jen v antisemitském pohledu (hledisku) se může „olejkár“ stát představitelem „záhubného řízení židovstva“ a podobná hetero-identita dané či jakkoli podobné postavě může být (a právě jen takto zlovolně či dokonce vyhraněně nenávistně), připisována, podsouvána, sugerována.

Druhý podnět souvisí s monografií těsněji a je zcela praktický: zdá se mi, že kniha nepřímo volá po potřebě šířeji založené publikace, tak řečeno „uživatelsky komfortní“, nejlépe proto slovníkové, encyklopedické, v níž by byly zastoupeny osobnosti nebo snad lépe vybraná epická, lyrická či dramatická díla, jež jsou reprezentativní pro slovenskou (případně slovensko-židovskou) literaturu nebo - snad lépe - „literaturu slovenského kulturního prostoru“ a s ním asociovaná (včetně děl německého, mad’arského, českého i jiného literárního jazyka). V této souvislosti připomeňme i „hlavový román“ (pojem Iva Pospíssila) z pera Jána Tužinského Kto hodi kameňom (židovské téma jako integrální součást národního slovenského života, jedno z jeho „zrcadel“), novelu Ladislava Grosmana Obchod na korze (už vzhledem k československé filmové adaptaci) nebo vzpomínky lékaře a filantropa Pavla Strausse (křestanství jako novožidovství).

Publikace představuje nejen kvalitní výstup z grantového projektu, ale také dobrý základ k dalším výzkumům, které na sebe - pravděpodobně - nenechají dlouho čekat.

\section{PhDr. et PaedDr. Alexej Mikulášek}

Stredoeurópske areálové štúdiá

Fakulta stredoeurópskych štúdií, Univerzita Konštantína Filozofa

Dražovská 4, 94974 Nitra, Slovensko

alexej.mikulasek@seznam.cz

Toto dílo Ize užít v souladu s licenčními podmínkami Creative Commons BY-SA 4.0 International (https://creativecommons.org/licenses/by-sa/4.0/legalcode). Uvedené se nevztahuje na díla či prvky (např. obrazovou či fotografickou dokumentaci), které jsou v díle užity na základě smluvní licence nebo výjimky či omezení přislušných práv. 